\title{
Postconditioning effect in the hepatic ischemia and reperfusion in rats $^{1}$
}

\author{
Efeito do pós-condicionamento isquêmico sobre a isquemia e reperfusão hepática em ratos
}

\author{
Carlos Henrique Marques dos Santos ${ }^{\mathrm{I}}$, José Carlos Dorsa Vieira Pontes ${ }^{\mathrm{II}}$, Luciana Nakao Odashiro Miiji ${ }^{\mathrm{III}}$, Diogo Iengo \\ Nakamura $^{I V}$, Cesar Augusto Vendas Galhardo ${ }^{\mathrm{V}}$, Sandra Maura Aguena ${ }^{\mathrm{VI}}$ \\ ${ }^{\mathrm{I}} \mathrm{PhD}$, Assistant Professor, Surgery Department, UFMS, Mato Grosso do Sul, Brazil. \\ ${ }^{I I}$ Associate Professor, Surgery Department, UFMS, Mato Grosso do Sul, Brazil.

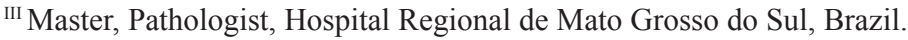 \\ ${ }^{\text {Iv }}$ MD. Resident, Hospital Regional de Mato Grosso do Sul, Brazil. \\ ${ }^{v}$ MD. Resident, UFMS, Mato Grosso do Sul, Brazil.

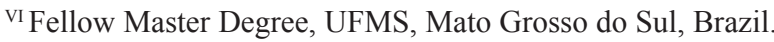

\begin{abstract}
Purpose: To evaluate the effect of postconditioning protection in liver tissue of rats submitted to ischemia and reperfusion. Methods: 25 Wistar male rats were randomized in three groups: Group A (ischemia and reperfusion - I/R), with 10 rats, which was made ischemia by vascular clamp application in hepatic hilum for 30 minutes and reperfusion for 60 minutes by removal of the clamp; Group B (Postconditioning - IPo), with 10 rats, with same procedure plus postconditioning ( 3 cycles of reperfusion inserted by 3 cycles of ischemia, 30 seconds for each phase, between ischemia and reperfusion phases); and Group C (Sham), with 5 rats, which took place only laparotomy and manipulation of the hepatic hilum. Specimens were examined (histological evaluation) and dosage of serum AST and ALT was made. The statistical analysis was made with $t$ Student test, with significant difference when $\mathrm{p}<0.05$. Results: In the Sham group there was no histological or enzymatic changes; In group A the mean tissue lesion was 1.6 and in group B 1.1 ( $\mathrm{p}=0.014$ ). In group A the mean ALT level was 355U/1 and in group B was 175.9U/1 ( $\mathrm{p}=0.016)$. The mean of AST was $828.8 \mathrm{U} / 1$ in group A and 295.5U/1 in group $B(p=0.001)$. Conclusion: The postconditioning was able to minimize the severity of liver injury in rats submitted to ischemia and reperfusion.
\end{abstract}

Key words: Ischemia. Reperfusion. Liver. Rats.

\section{RESUMO}

Objetivo: Avaliar o efeito do pós-condicionamento isquêmico na proteção tecidual hepática de ratos submetidos à isquemia e reperfusão. Métodos: Foram utilizados 25 ratos da linhagem Wistar provenientes do Biotério da Universidade Federal de Mato Grosso do Sul, distribuídos em três grupos: A) grupo isquemia/reperfusão (I/R) (10 ratos), em que foi realizada isquemia e reperfusão hepática pela aplicação e retirada de clampe do hilo hepático durante 30 e 60 minutos, respectivamente; B) grupo pós-condicionamento isquêmico (PoCI) (10 ratos), em que foi realizado procedimento semelhante ao anterior, exceto pela realização do pós-condicionamento isquêmico entre as fases de isquemia e reperfusão, consistindo na retirada e colocação do clampe do hilo hepático por 30 segundos cada fase, durante 3 ciclos; grupo C (Sham) (5 ratos), em que realizou-se apenas laparotomia e manipulação do hilo hepático. Foram analisados os espécimes (avaliação histológica), dosagem sorológica de AST e ALT. Resultados: No grupo Sham não se observou alterações histológicas nem enzimáticas; no grupo A a média de lesão tecidual foi 1,6 e no grupo B 1,1 ( $\mathrm{p}=0,014)$. No grupo A a média de ALT foi 355U/1 e no grupo B 175,9U/1 (p=0,016). A média de AST foi de 582,8U/1 no grupo A e 295,5U/1 no grupo B (p=0,001). Conclusão: $\mathrm{O}$ pós-condicionamento isquêmico foi capaz de minimizar a intensidade das lesões hepáticas de ratos submetidos à isquemia e reperfusão.

Descritores: Isquemia. Reperfusão. Fígado. Ratos.

${ }^{1}$ Research performed at Laboratory of Researches of Federal University of Mato Grosso do Sul (UFMS), Brazil. 


\section{Introduction}

The operations of the liver, especially the resection and transplantation, are usually performed with temporary occlusion of the hepatic hilum to prevent bleeding. However, this occlusion leads to ischemia followed by reperfusion, which can cause damage to hepatocytes and distance, often worsening the clinical situation of patients ${ }^{1,2}$.

The process of ischemia for many years has been studied and the knowledge about its physiopathology has evolved so considerable ${ }^{3}$. The reperfusion, logical step in dealing with any situation of ischemia, is now regarded as an important factor in the deterioration of the framework for local and systemic injury since predisposes to the formation of the so called reactive oxygen species that are responsible for direct tissue injury ${ }^{4}$.

This knowledge has led many researchers to search for a method capable of minimizing the damage caused during reperfusion, and highlights the use of some drugs for this purpose ${ }^{5}$. However, there is no medicine to benefit large enough to use in clinical practice for patients with ischemia ${ }^{6}$.

Recently, Zhao et al. ${ }^{7}$ proposed a method to achieve this purpose, called postconditioning (IPo), based on studies of preconditioning (IPr) provided by Murry et al. ${ }^{8}$. The postconditioning is the achievement of one or more short reperfusion periods inserted by one or more short ischemia periods, made soon after the ischemia phase and before reperfusion phase.

This method was used successfully in myocardial ${ }^{7}$, brain $^{9}$, kidney $^{10}$, spinal cord ${ }^{11}$, intestine ${ }^{12}$ and, recently, just one study that demonstrate its efficacy in liver ${ }^{13}$ ischemia and reperfusion, which justifies this study.

\section{Purpose}

To evaluate the protective effect of postconditioning in hepatic ischemia and reperfusion process in rats.

\section{Methods}

The research received approval from Ethic Committee of Federal University of Mato Grosso do Sul and was followed ethical principles advocated by Brazilian College of Animal Experimentation.

Was used 25 rats (Rattus norvegicus albinus, Rodentia, Mammalia), Wistar, male, adult, from the labs of Federal University of Mato Grosso do Sul.

The animals were distributed into three groups: group A (ischemia and reperfusion - I/R), with 10 animals, group B (postconditioning - IPo), with 10 animals and group C (Sham) with 5 animals.

The rats were weighed and then anesthetized by intraperitoneal injection of 2:1 soluction of ketamine hydrochloride $\left(\right.$ Cetamin $\left.^{\circledR}\right), 50 \mathrm{mg} / \mathrm{ml}$, and Xylazine hydrochloride $\left(\right.$ Xilazin $\left.^{\circledR}\right)$, $20 \mathrm{mg} / \mathrm{ml}$, respectively, in the dose of $0.1 \mathrm{ml} / 100 \mathrm{~g}$. The rats were operated after having observed the loss of palpebral reflex, loss of response to mechanical stimuli, loss of reflexes of straightening and removal of the member after painful stimulus caused by gripping.
After anesthetized, there was abdominal trichotomy and positioning of the animal on the operating table in supine position, with four members in abduction.

In all animals there was longitudinal median laparotomy of approximately $4 \mathrm{~cm}$ to access the abdominal cavity. In the group $\mathrm{C}$ animals was held hepatic hilum manipulation only and closed of abdominal cavity; after 90 minutes was held laparotomy again to remove hepatic fragment and blood sample. In other rats the hepatic hilum was dissected and isolated and an atraumatic clamp was applied, starting the ischemia phase that lasted 30 minutes. During the ischemia, the abdominal cavity was closed, thus avoiding water loss and hypothermia. Completed ischemia phase, the abdominal cavity was opened again for the removal of the vascular clamp and it begins the reperfusion phase, lasting for 60 minutes. Only in group B was held the postconditioning by 3 cycles of reperfusion inserted by 3 cycles of ischemia, with 30 seconds each one. The reperfusion and ischemia were made by the removal and reapplication of vascular clamp on the hepatic hilum. Started reperfusion, the abdominal cavity was closed again until the end of experiment when blood samples were collected for assay of enzymes Aspartate aminotransferase (AST) and Alanine aminotransferase (ALT) and a liver fragment was resected and placed on formaldehyde at $10 \%$ solution for further histological analysis. The animals were submitted to euthanasia for the deepening of the anesthetic level.

The strengths of the liver enzymes were performed at the Laboratory of Clinical Analysis of the University Hospital of the Federal University of Mato Grosso do Sul.

The liver samples were properly prepared, stained (hematoxylin-eosin) and the slides were examined blindly by the pathologist. The specimens were scored according to the histological extension of the lesion as follows: 0 when there was no histological changes; grade 1, centrolobular congestion; grade 2, centrolobular congestion with some degeneration of hepatocytes, in one or two central vein and grade 3, multifocal centrolobular and portal congestion and degeneration of hepatocytes.

The results were submitted to statistical analysis by $t$ Student test, considering significant $\mathrm{p}<0.05$.

\section{Results}

Macro and microvesicular steatosis were seen in some cases, mainly peri terminal hepatic venule, and this finding was not correlated with histological scores. No inflammation was seen. The animals of group Sham presented no tissue injury. In group A were obtained grades 1 and 2 of lesions, with average of 1.6, while one animal in group B presented no injury and the others had lesions grade 1 and 2, averaging 1.1 (Table 1).

Evaluation of serum ALT showed a statiscally significant difference between groups. In group A the average was 355U/1, in group B 175.9U/1 and in group C 65.2U/1 (Table 2).

The determination of AST also showed statiscally significant difference between three groups. In group $\mathrm{A}$ the average was 582.8U/1, in group B 295.5U/1 and in group C 138.6U/1 (Table 3). 
TABLE 1 - Grades of hepatic tissue lesion in the studied groups

\begin{tabular}{cccc}
\hline Rat & \multicolumn{3}{c}{ Grade of tissue lesion } \\
\cline { 2 - 4 } 1 & Group A & Group B & Group C \\
2 & 2 & 1 & 0 \\
3 & 2 & 1 & 0 \\
4 & 1 & 1 & 0 \\
5 & 1 & 1 & 0 \\
6 & 2 & 1 & 0 \\
7 & 2 & 2 & \\
8 & 1 & 0 & \\
9 & 2 & 2 & 0 \\
\hline 10 & 1 & 1 & \\
Average & 2 & 1 & \\
\hline
\end{tabular}

$\mathrm{p}=0.014$

TABLE 2 - Results of Alanine Aminotransferase (ALT) in the studied groups

\begin{tabular}{cccc}
\hline \multirow{2}{*}{ Rat } & \multicolumn{3}{c}{ Values of ALT in U/I } \\
\cline { 2 - 4 } 1 & Group A & Group B & Group C \\
2 & 454 & 189 & 63 \\
3 & 216 & 243 & 69 \\
4 & 427 & 208 & 63 \\
5 & 200 & 194 & 74 \\
6 & 783 & 137 & 57 \\
7 & 340 & 201 & \\
8 & 313 & 124 & \\
9 & 149 & 145 & \\
\hline 10 & 391 & 204 & 65.2 \\
\hline Average & 277 & 114 & \\
\hline
\end{tabular}

$\mathrm{p}=0.016$ between $\mathrm{A}$ and $\mathrm{B}$ $\mathrm{p}=0.031$ between $\mathrm{A}$ and $\mathrm{C}$ $\mathrm{p}=0.001$ between $\mathrm{B}$ and $\mathrm{C}$ 
TABLE 3 - Values of Aspartate Aminotransferase (AST) between the groups

\begin{tabular}{cccc}
\hline Rat & \multicolumn{3}{c}{ Values of AST in U/I } \\
\cline { 2 - 4 } 1 & Group A & Group B & Group C \\
2 & 566 & 284 & 126 \\
3 & 462 & 249 & 133 \\
4 & 813 & 367 & 137 \\
5 & 365 & 291 & 167 \\
6 & 987 & 337 & 130 \\
7 & 798 & 281 & \\
8 & 571 & 302 & \\
9 & 364 & 298 & \\
10 & 433 & 244 & \\
Average & 469 & 302 & 138.6 \\
\hline
\end{tabular}

$\mathrm{p}=0.001$ between $\mathrm{A}$ and $\mathrm{B}$

$p=0.013$ between $A$ and $C$

$p=0.001$ between $B$ and $C$

The Figures 1 to 3 show the histological changes in the groups.

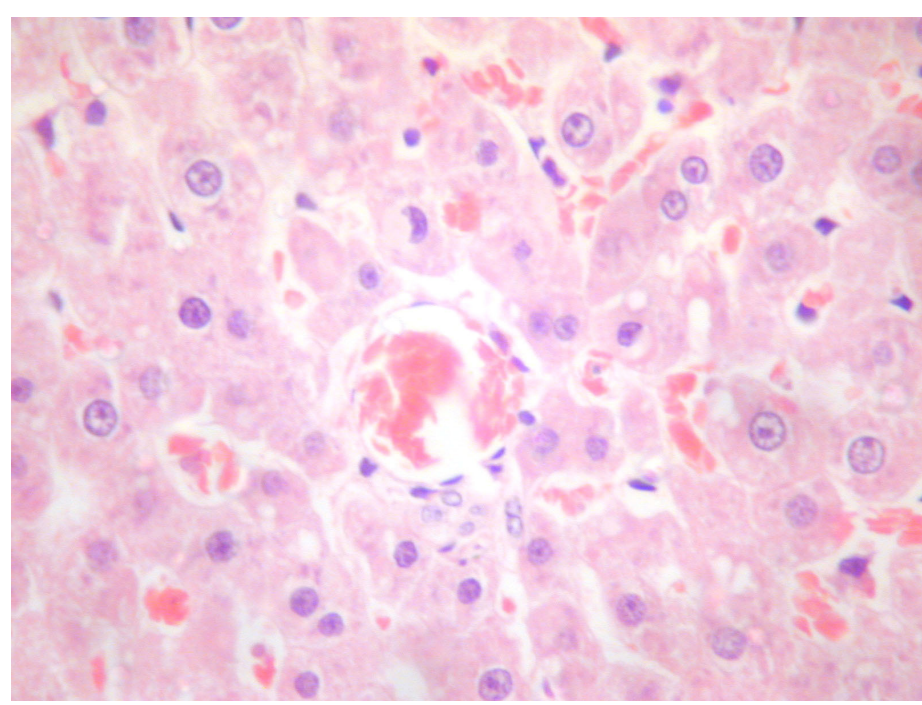

FIGURE 1 - Histological aspect of grade 1 liver lesion - centrolobular congestion (HE 400X)

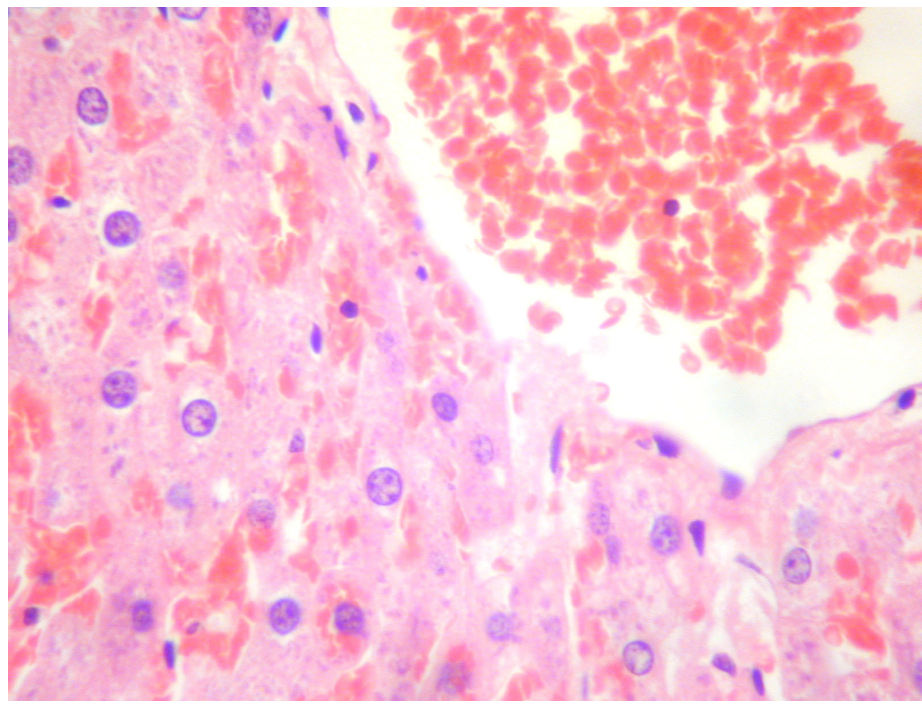

FIGURE 2 - Histological aspect of grade 2 liver lesion - centrolobular congestion with some degeneration of hepatocytes (HE 400X) 


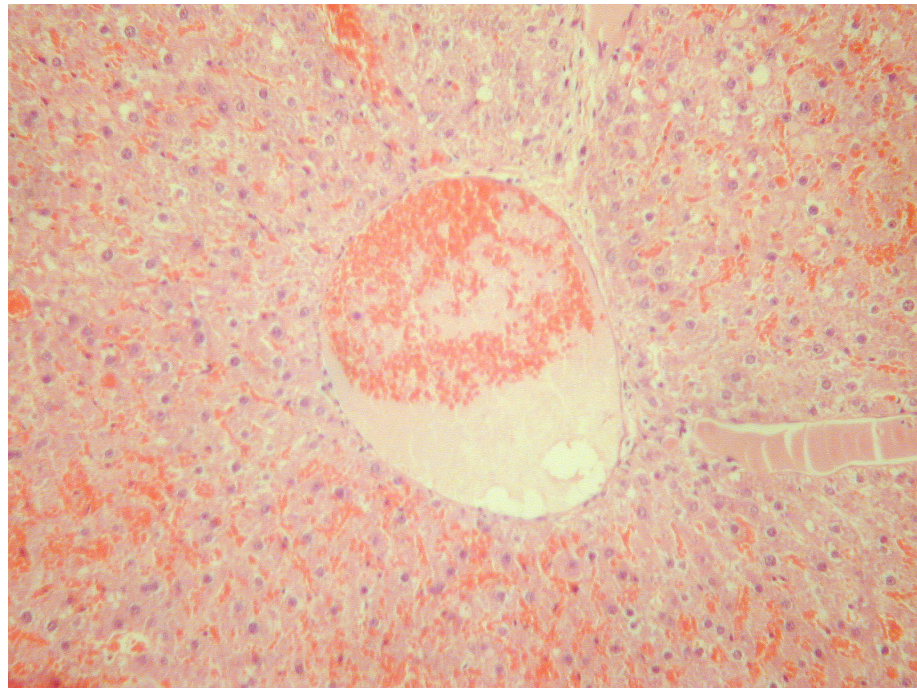

FIGURE 3 - Histological aspect of grade 3 liver lesion - multifocal centrolobular and portal congestion and degeneration of hepatocytes (HE 100X)

\section{Discussion}

Situations such as transplantation and hepatic resections, performed under hepatic hilum clamping naturally lead to reperfusion, with all the negative consequences related to it. Avoid or minimize such effects is crucial and has been the subject of numerous studies.

The IPr made by Murry et al. ${ }^{8}$ was of great value in this respect, and served as the inspiration for the creation of the IPo described by Zhao et al. ${ }^{7}$, which has been used successfully in situations of ischemia and reperfusion.

Elevated levels of AST and ALT is observed experimentally in hepatic ischemia and reperfusion ${ }^{2,14}$, which is also observed in group I/R of this research, whereas in the Sham group there was no elevation of these enzymes. In group IPo, levels of AST and ALT were increased with lower intensity, demonstrating the protective effect of this procedure in hepatic ischemia and reperfusion.

The cellular changes of hepatocytes subjected to ischemia and reperfusion can be evaluated histologically, as already demonstrated in other studies ${ }^{2}$. We found in this study histological changes in groups I/R and IPo, but with less intensity in this, while rats in the Sham group no changes were observed. These findings corroborate the results observed in relation to enzymatic changes, confirming the protective effect of IPo in hepatic ischemia and reperfusion.

In Brazil, Teixeira et al. ${ }^{13}$ also evaluated the postconditioning effect in rat liver, demonstrating its protective capacity. However, using different methods, using 60 minutes of ischemia, 120 minutes of reperfusion and postconditioning with 5 cycles of reperfusion and ischemia with 5 seconds each one. Also the method of evaluation was different, determination of malondialdehyde level and expression of the glutathione-stransferase-a-3 gene.
A poor number of researches about hepatic postconditioning makes hard comparation between them, and be impossible to compare the method of use postconditioning. Similarly, in studies of IPr and IPo of other organs, there is great variation in the time of ischemia, time of reperfusion, number and time of cycles of ischemia and reperfusion, without, however, this leads to compromise the outcomes.

As has been demonstrated in situations of intestinal ischemia and reperfusion ${ }^{12}$, renal ${ }^{13}$, cerebral ${ }^{9}$ and spinal cord $^{11}$, also in the liver of rats we can see the capacity of IPo of to minimize the damage resulting of this process.

\section{Conclusion}

The postconditioning was able to minimize the severity of liver injury in rats submitted to ischemia and reperfusion.

\section{References}

1. Castro e Silva Jr O, Centurion S, Pacheco EG, Brisotti JL, Oliveira AF, Sasso KD. Aspectos básicos da lesão de isquemia e reperfusão e do précondicionamento isquêmico. Acta Cir Bras. 2002;17(3):96-100.

2. Miranda LEC, Viaro F, Ceneviva R, Evora PRB. As bases experimentais da lesão por isquemia e reperfusão do fígado. Revisão. Acta Cir Bras. 2004;19(1):1-12.

3. Parks DA, Granger DN. Contributions of ischemia and reperfusion to mucosal lesion formation. Am J Physiol. 1986;250:749-53.

4. Menon NJ, Amin AM, Mohamed A, Hamilton G. Acute mesenteric ischaemia. Acta Chir Belg. 2005;105:344-54.

5. Santos CHM, Gomes OM, Pontes JCDV, Miiji LNO, Higa EI. Uso do propofol (2,6 diisopropilfenol) como inibidor da lesão tecidual na isquemia e reperfusão mesentérica. Estudo experimental em ratos. Acta Cir Bras. 2003;18(4):347-54.

6. Santos CHM, Gomes OM, Pontes JCDV. Terapêutica medicamentosa na isquemia e reperfusão mesentérica: revisão da literatura. Rev Bras Coloproctol. 2006;26(1):28-33.

7. Zhao ZQ, Corvera JS, Halkos ME, Kerendi F, Wang NP, Guyton RA, Vinten-Johansen J. Inhibition of myocardial injury by ischemic postconditioning during reperfusion: comparison with ischemic preconditioning. Am J Physiol Heart Circ Physiol. 2003;285:579-88.

8. Murry CE, Jennings RB, Reimer KA. Preconditioning with ischemia: a delay of lethal cell injury in ischemic myocardium. Circulation. 1986;74:1124-36.

9. Rehni AK, Singh N. Role of phosphoinositide 3-kinase in ischemic postconditioning-induced attenuation of cerebral ischemia-evoked behavioral deficits in mice. Pharmacol Rep. 2007;59:192-8.

10. Liu X, Chen H, Zhan B, Xing B, Zhou J, Zhu H, Chen Z. Attenuation of reperfusion injury by renal ischemic postconditioning: the role of NO. Biochem Biophys Res Commun. 2007;359:628-34.

11. Huang H, Zhang L, Wang Y, Yao J, Weng H, Wu H, Chen Z, Liu J. Effect of ischemic post-conditioning on spinal cord ischemic-reperfusion injury in rabbits. Can J Anaesth. 2007;54:42-8.

12. Santos CHM, Gomes OM, Pontes JCDV, Miiji LNO, Bispo MA. The ischemic preconditioning and postconditioning effect on the intestinal mucosa of rats undergoing mesenteric ischemia/reperfusion process. Acta Cir Bras. 2008;23(1):22-8.

13. Teixeira ARF, Molan NT, Kubrusly MS, Bellodi-Privato M, Coelho AM, Leite KR, Machado MAC, Bacchella T, Machado MCC. Postconditioning ameliorates lipid peroxidation in liver ischemiareperfusion injury in rats. Acta Cir Bras. [serial on the Internet] 2009 Jan-Feb;24(1). Available from URL: http://www.scielo.br/acb 
14. Schipke JD, Halkos ME, Kerendi F, Gams E, Vinten-Johansen J.

Postconditioning: a brief review. Arch Med Sci. 2006;2:137-45.

Conflict of interest: none Financial source: none

\section{Correspondence:}

Carlos Henrique Marques dos Santos

Rua Aluisio de Azevedo, 606

79004-050 Campo Grande - MS Brazil

chenriquems@yahoo.com.br

Received: April 15, 2009

Review: June 18, 2009

Accepted: July 15, 2009

\section{How to cite this article}

Santos CHM, Pontes JCDV, Miiji LNO, Nakamura DI, Galhardo CAV, Aguena SM. Postconditioning effect in the hepatic ischemia and reperfusion in rats. Acta Cir Bras. [serial on the Internet] 2010 Mar-Apr;25(2). Available from URL: http://www.scielo.br/acb 